\title{
A stem falconid bird from the Lower Eocene of Antarctica and the early southern radiation of the falcons
}

\author{
Marcos Cenizo $^{1,2} \cdot$ Jorge I. Noriega $^{3} \cdot$ Marcelo A. Reguero $^{4}$
}

Received: 10 September 2015/Revised: 24 November 2015/ Accepted: 4 December 2015

(C) Dt. Ornithologen-Gesellschaft e.V. 2016

\begin{abstract}
Antarctoboenus carlinii nov. gen. nov. sp. is a large-sized falconiform bird from the La Meseta Formation (Lower Eocene) at Seymour (Marambio) Island, West Antarctica. The holotypical tarsometatarsus was originally assigned to Falconidae and its affinities to Polyborinae were pointed out. Detailed osteological and comparative analyses of the Antarctic specimen allowed recognition of the new taxon as a member of stem group Falconidae, i.e. it is supposed to belong to the early radiation of the falconiform lineage. Antarctoboenus carlinii is distinguished from members of crown group Falconidae by having a very shallow sulcus extensorius, a large foramen vasculare distale, an undistinguishable tendinal attachment for the $\mathrm{m}$. adductor digiti II, and short trochlea metatarsi II, among its main diagnostic characters. Purported phylogenetic relationships between A. carlinii and Polyborinae are based on plesiomorphic characters retained in the tarsometatarsus of the latter clade. Our conclusions reinforce the hypothesis
\end{abstract}

Communicated by J. Fjeldså.

Marcos Cenizo

cenizomarcos@yahoo.com.ar

1 Área Paleontología, Museo Provincial de Historia Natural, Pellegrini 180, 6300 Santa Rosa, La Pampa, Argentina

2 Fundación de Historia Natural Félix de Azara, Departamento de Ciencias Naturales y Antropología, CEBBAD-

Universidad Maimónides, Hidalgo 775,

C1405BDB Buenos Aires, Argentina

3 Laboratorio de Paleontología de Vertebrados, CICYTTPCONICET, UADER, Materi and España, 3105 Diamante, Entre Ríos, Argentina

4 Instituto Antártico Argentino, Balcarce 290, C1064AAF Buenos Aires, Argentina about the Neotropical or Austral origin of Falconidae supported by previous molecular phylogenies.

Keywords Fossil bird - Falconiformes - Paleogene · Seymour Island - Stem lineage $\cdot$ Antarctoboenus carlinii

\section{Zusammenfassung}

Ein der Stammgruppe Falconidae angehörender Vogel aus dem Untereozän der Antarktis und die frühe südliche Radiation der Falken

Antarctoboenus carlinii nov. gen. nov. sp. ist ein großer falkenartiger Vogel aus der La Meseta Formation (Untereozän) auf der Seymour-Insel (Isla Marambio) in der Westantarktis. Der Holotyp-Tarsometatarsus wurde ursprünglich den Falconidae (Falkenartigen) zugeordnet, und seine Ähnlichkeiten mit den Polyborinae (Geierfalken) wurden hervorgehoben. Detaillierte osteologische und vergleichende Analysen des Antarktis-Exemplars ermöglichten es, das neue Taxon als ein Mitglied der Stammgruppe Falconidae anzuerkennen, d.h. es gehört vermutlich der frühen Radiation der Falconiformes-Abstammungslinie an. Antarctoboenus carlinii unterscheidet sich von den Mitgliedern der Kronengruppe Falconidae durch mehrere diagnostische Merkmale, u.a. einen sehr flachen sulcus extensorius, ein großes foramen vasculare distale, einen undeutlichen Sehnenansatz für den m. adductor digiti II und kurze trochlea metatarsi II. Angebliche phylogenetische Beziehungen zwischen A. carlinii und Polyborinae basieren auf plesiomorphen Merkmalen, die im Tarsometatarsus der Polyborinae erhalten sind. Unsere Schlussfolgerungen stärken die Hypothese eines Neotropen- oder Austral-Ursprungs der Falconidae, die auch von bisherigen molekularen Stammbäumen gestützt wird. 


\section{Introduction}

The avian family Falconidae constitutes a group of small to medium-sized diurnal raptors whose monophyly is strongly supported (e.g. Griffiths et al. 2004; Wink and Sauer-Gürth 2004; Fuchs et al. 2015). It is accepted that the family radiation comprised three major clades, generally recognized at subfamiliar rank: Herpetotherinae, Polyborinae, and Falconinae (Griffiths 1999; Griffiths et al. 2004; Fuchs et al. 2011, 2012, 2015; Noriega et al. 2011). The Herpetotherinae includes the Forest Falcons of the genus $M i$ crastur and the monotypic Herpetotheres cachinnans commonly known as Laughing Falcon. The Polyborinae comprises the Caracaras (i.e. Caracara, Phalcoboenus, Ibycter, Daptrius, and Milvago) and the Spot-winged Falconet Spiziapteryx circumcincta. Finally, the Falconinae includes the Old World Falconets Microhierax and the Pygmy-falcons Polihierax, together with true falcons and allies belonging to the genus Falco.

With the exception of the almost worldwide distribution of Falco and the Afro-Asian range of Polihierax and $\mathrm{Mi}$ crohierax, the remaining diversity of falconids is concentrated in the Neotropics (Olson 1976; White et al. 1994; Ferguson-Lees and Christie 2001; Fuchs et al. 2015). This fact led to the consideration that most of their evolutionary history occurred in South America and that the Falconinae had derived from primitive neotropical forms (Olson 1976; Ericson 2012). However, the scarce paleogene fossil record for the group does not bring conclusive evidence to support the purported Neotropical or Austral origin of its main clades (White et al. 1994; Feduccia 1996).

Tambussi et al. (1995) reported the presence of a probable Polyborinae at Lower Eocene deposits in Antarctica (Fig. 1) in a brief abstract, but although it constituted a relevant finding because of its geographic provenance and age, the material has never been thoroughly analyzed, nor figured or formally described. Herein, we make an exhaustive revision and comparative study of the Antarctic specimen, proposing a new phylogenetic position of this taxon with respect to extant and extinct falconid lineages.

\section{Materials and methods}

\section{Institutional abbreviations}

BMNH British Museum of Natural History, London, UK

CFA-OR Ornithological Collection, Fundación de Historia Natural "Félix de Azara", Buenos Aires, Argentina

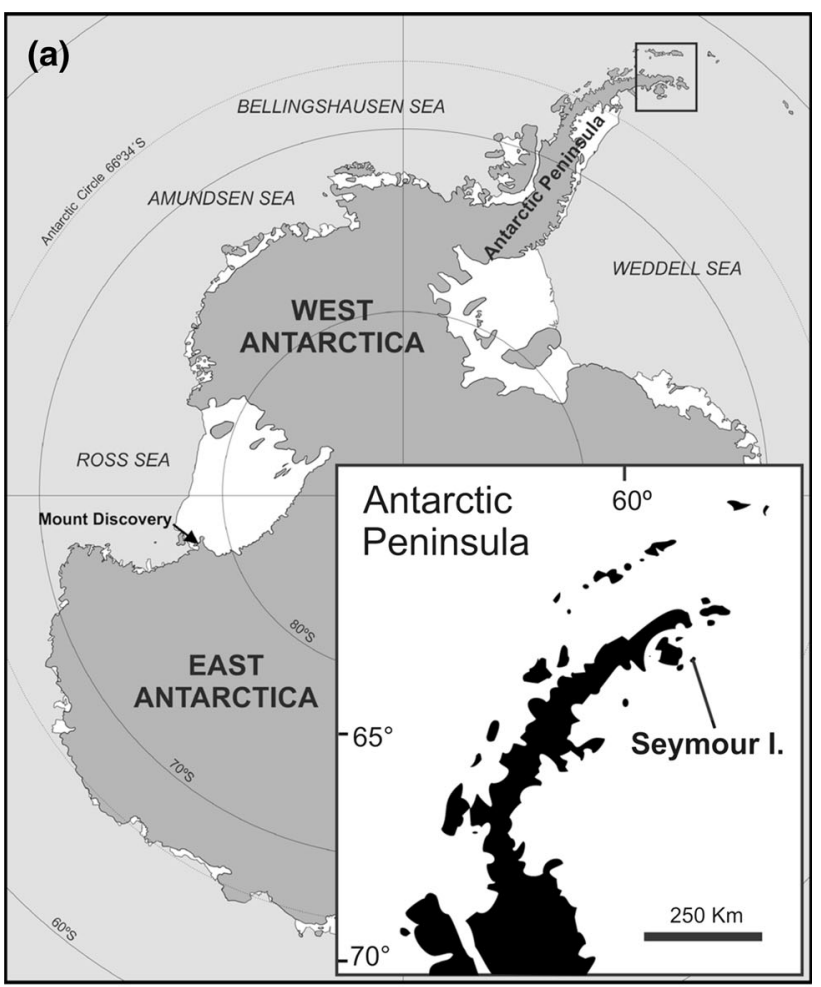

(b) Seymour Island

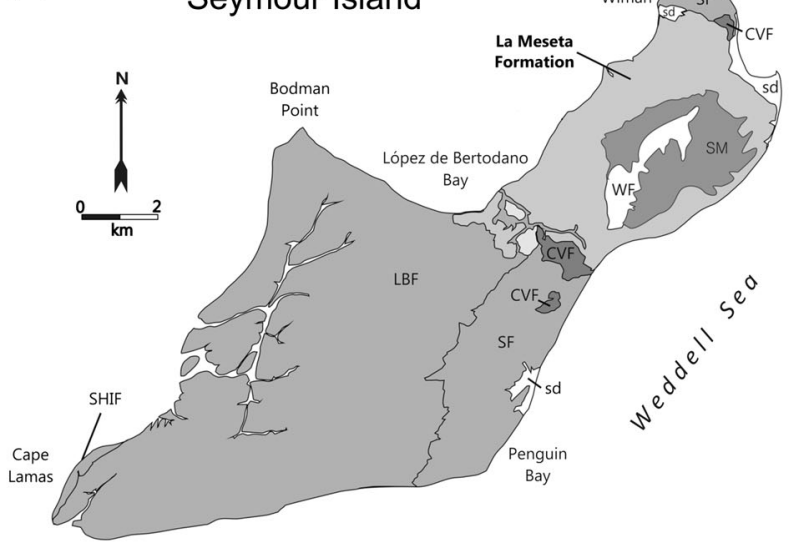

Fig. 1 a Geographical location of Seymour Island in Antarctic Peninsula (West Antarctica). b Geological map of Seymour Island indicating the outcrops of La Meseta Formation. Other stratigraphic units are also indicated: $C V F$ Cross Valley Formation, $L B F$ López de Bertodano Formation, SF Sobral Formation, SM Submeseta Formation, $W F$ Weddel Formation, $s d$ surficial deposits

MACN Museo Argentino de Ciencias Naturales, Buenos Aires, Argentina

MHNT Museu de História Natural de Taubaté, Taubaté, Brazil

MLP Museo de La Plata, La Plata, Argentina

MPM-PV Paleontological Collection, Museo Regional Provincial "Padre M. J. Molina", Río Gallegos, Santa Cruz, Argentina 
Comparisons included the following living species deposited at CFA-OR, MACN, and MHNT collections: Accipiter striatus, Rupornis magnirostris, Buteo polyosoma, Parabuteo unicinctus, Cariama cristata, Chunga burmeisteri, Micrastur ruficollis, M. semitorquatus, Herpetotheres cachinnans, Spiziapteryx circumcincta, Polyborus plancus, Milvago chimango, M. chimachima, Phalcoboenus albogularis, P. australis, Polihierax semitorquatus, Falco mexicanus, $F$. rusticolus, $F$. peregrinus, $F$. tinnunculus, $F$. columbarius, F. femoralis, and F. sparverius. Holotypical specimens and additional materials of the following extinct falcons were also compared: Thegornis musculosus (BMNH-A600, MPM-PV-3443; Santa Cruz Formation, Lower Miocene, Santa Cruz Province, Argentina; see Ameghino 1895; Noriega et al. 2011), T. debilis (BMNHA601; Santa Cruz Formation, Lower Miocene, Santa Cruz Province, Argentina; see Ameghino 1895; Noriega et al. 2011), and Badiostes patagonicus (BMNH-A602; Santa Cruz Formation, Lower Miocene, Santa Cruz Province, Argentina; see Ameghino 1895; Noriega et al. 2011). Data from other Miocene taxa as Pediohierax ramenta and Falco hezhengensis were extracted from their published descriptions and figures (Wetmore 1936; Becker 1987; Li et al. 2014).

The measurements are in millimeters and were taken with a Vernier caliper of $0.01 \mathrm{~mm}$ of resolution. Osteological nomenclature follows Baumel and Witmer (1993).

\section{Results}

\section{Systematic palaeontology}

\author{
Class Aves LINNAEUS 1758 \\ Order Falconiformes SHARPE 1874 \\ Family Incertae sedis \\ Genus Antarctoboenus nov.
}

\section{Type species Antarctoboenus carlinii}

Diagnosis Large-sized falconiform bird, similar to Polyborus plancus in overall dimensions. The following characters distinguish it from other extinct or extant taxa of the crown group Falconidae: (1) distal end of sulcus extensorius very shallow; (2) dorsal opening of the foramen vasculare distale large; (3) tendinal attachment for $\mathrm{m}$. adductor digiti II undistinguishable; (4) trochlea metatarsi II short (i.e. distally not exceed the half of trochlea metatarsi III); (5) medial divergence of trochlea metatarsi II weak; (6) in plantar view, incisura intertrochlearis lateralis well developed proximally; (7) in distal view, incisurae intertrochlearis medialis et lateralis wide.
Additionally, the new taxon is characterized by the following combination of features: (1) shaft narrowed (vs. shaft broadened in Herpetoheres, Thegornis, and largesized Falco spp.); (2) cross-section of the tarsometatarsal midshaft squared (vs. triangular in Herpethoteres; "H" shaped in Thegornis and Micrastur); (3) dorsal surface of shaft flattened, without cristae (vs. medial crista developed in Herpetotheres; both medial and lateral cristae developed in Micrastur and Thegornis); (4) crista plantaris medialis not prominent and projected nearly vertical towards the proximal end (vs. both cristae plantare medialis et lateralis strongly developed in Herpetotherinae; crista plantaris medialis more laterally projected in Falconinae); (5) absence of bony channel for $\mathrm{m}$. extensor brevis digiti IV at the level or above the dorsal opening of the foramen vasculare distale (evident due to the presence of two foramina on the dorsal surface; vs. channel normally present in Polyborinae and Falconinae); (6) plantar opening of the foramen vasculare distale large and proximally located (vs. reduced and more distally positioned in Herpetotheres, Thegornis, Spiziapteryx, Pediohierax, and Falconinae; reduced and more proximal in Micrastur); (7) fossa metatarsi I poorly defined, relatively wide, shallow, and distally located (vs. narrow and more proximal in $\mathrm{Mi}$ crastur; deeper in Herpetotheres and Thegornis; wider and well defined in Polyborus and Phalcoboenus); (8) absence of a wide indentation on medial surface (vs. present in Herpetotherinae); (9) area of insertion of $\mathrm{m}$. abductor digiti II on trochlea metatarsi II reduced (vs. large, continuous with the sulcus extensorius in Herpetotherinae, as well as in Falconinae, but less marked); (10) canalis interosseus distalis totally ossified, i.e. distal notch absent (vs. canalis absent or incomplete in Herpetotheres and Falconinae, i.e. distal notch present); (11) fossa supratrochlearis plantaris relatively deep (vs. shallow in Herpetotherinae); (12) trochlea metatarsi IV short (vs. more distally extended in most falconids, except in Falco where it is even shorter); (13) in dorsal view, proximomedial constriction (fovea lig. collateralis) above trochlea metatarsi II absent (vs. present in Herpetotherinae, Pediohierax and Falconinae); (14) articular plantar surface of trochlea metatarsi III elongated (vs. short and wide in Herpetotherinae and Falconinae); (15) trochlea metatarsi III not directed medially in dorsal view (vs. markedly directed medially in Thegornis, Micrastur, and Falconinae; weakly inclined in Herpetotheres); (16) in plantar view, lateral rim of trochlea metatarsi IV more distally projected than medial rim (vs. similar projections of both rims in Polyborinae and Falconinae); (17) in distal view, trochlea metatarsi IV laterally oriented, with lateral rim widened and plantarly shortened (vs. trochlea more dorsally oriented with lateral ridge narrow and plantarly extended in Polihierax and Herpetotherinae). 
Derivatio nominis Antarctic walker, from Antarcto, in reference to Antarctica, and boenus derived from the Greek "baino", to walk, in reference to the presumed plesiomorphic condition of the holotypical tarsometatarsus shared with the extant ground-dwelling polyborines (i.e. Phalcoboenus).

Species Antarctoboenus carlinii nov. Figure 2a-c.

Holotype MLP 95-I-10-8, distal end of left tarsometatarsus. Collected by Sergio Santillana during the Antarctic Summer Campaign of 1995.

Type locality IAA 2/95 locality, Seymour (Marambio) Island, Antarctic Peninsula, West Antarctica. The material comes from the Cucullaea I Allomember (level 35 in Montes et al. 2013) of the La Meseta Formation (Marenssi et al. 1998; Fig. 1a, b).

Age Middle Ypresian, Early Eocene. Strontium dating yielded ages of 52.8-49 million years ago for the level 35 of the Cucullaea I Allomember in the type locality (Montes et al. 2013).

\section{Diagnosis as for the genus}

Derivation nominis in honor of Dr. Alejandro Ricardo Carlini (1963-2010), leader of the argentine research program on reproductive and feeding ecology in Antarctic pinnipeds.

Measurements Distal width 22.2, midshaft width 9.4.
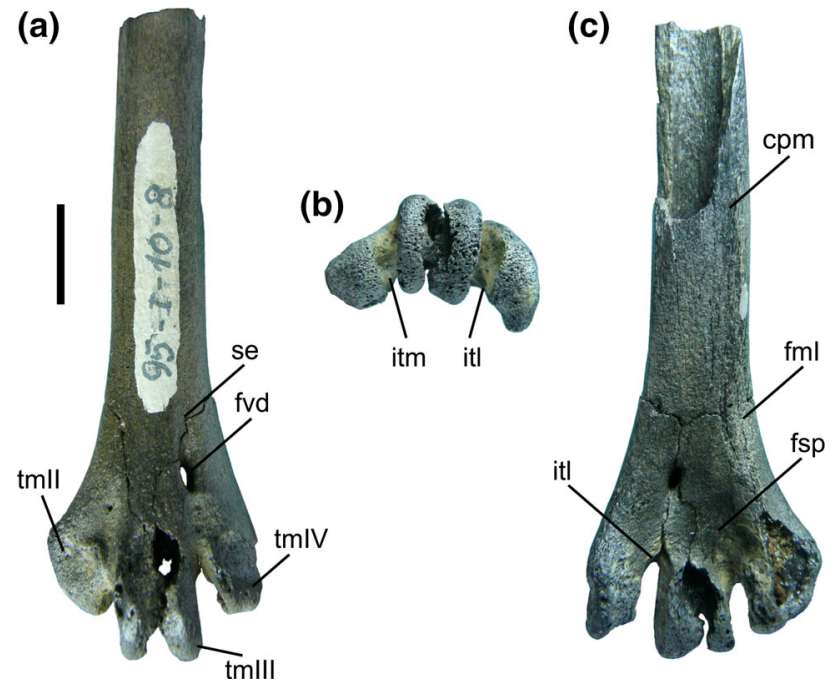

Fig. 2 Antarctoboenus carlinii nov. gen. nov. sp. from the Lower Eocene of Antarctic Peninsula. a Distal end of left tarsometatarsus, MLP 95-I-10-8, holotype, dorsal view. b Idem, distal view. c Idem, plantar view. cpm crista plantaris mediale, $f m I$ fossa metatarsi I, $f s p$ fossa supratrochlearis plantaris, $f v d$ foramen vasculare distale, it incisura intertrochlearis lateralis, itm incisura intertrochlearis medialis, se sulcus extensorius, $t m I I$ trochlea metatarsi II, tmIII trochlea metatarsi III, tmIV trochlea metatarsi IV. Scale bar $10 \mathrm{~mm}$

\section{Description and comparisons}

As in Micrastur, Polyborinae, the extinct Pediohierax and basal Falconinae (e.g. Polihierax spp., "tinnuculus" group of Falco), the shaft of Antarctoboenus carlinii is narrow, and considering the preserved fragment of bone, it seems to have been elongated, differing from the broadened and shorter of Herpetotheres, the allied Miocene Patagonian genus Thegornis, and some large-sized Falco spp. (e.g. F. rusticolis, $F$. peregrinus, $F$. mexicanus). The tarsometatarsal specimen is broken at midshaft, exhibiting a square cross-section as in Polyborinae and Falconinae. Contrarily, the midshaft presents a triangular cross-section due to reduction of the lateral surface of the bone in Herpetotheres, whereas the dorsal and plantar surfaces are strongly grooved, giving the shaft the typical H-shaped cross-section in Micrastur and Thegornis (see Jollie 1976, Fig. 140e; Noriega et al. 2011, Fig. 8). The dorsal surface of the preserved shaft in Antarctoboenus is flattened as in Polyborinae and Falconinae, differing from the development of a medial crest present in Herpetotheres, and of both medial and lateral ones in Micrastur and Thegornis. Crista plantaris medialis is not very prominent as shown in Polyborinae and Falconinae. This crest projects nearly vertical towards proximal end as it can be observed in Polyborinae and Pediohierax in plantar view, and does not incline laterally as in Falconinae. On the contrary, both cristae plantare medialis et lateralis are well developed in Herpetotherinae, delimiting a deep sulcus flexorius.

On the dorsal surface, the distal portion of the sulcus extensorius in Antarctoboenus is very shallow, being only slightly marked when joining the foramen vasculare distale; whereas this sulcus is somewhat more conspicuous in Polyborinae and Falconinae, exhibiting its major development in Herpetotherinae (Fig. 3a).

The canalis interosseus distalis which contains the tendon of $\mathrm{m}$. extensor brevis digiti IV (Baumel and Witmer 1993:113) is usually bordered distally by a bony channel at the level or above the dorsal opening of the foramen vasculare distale (Jollie 1976; Fig. 3a, ceIV). Thus, the distal end of the tarsometatarsus can show two adjacent lateral foramina, one above the other. Notwithstanding its variability, this condition is common in most Polyborinae and Falconinae (Becker 1987), being absent in Herpetotherinae and Antarctoboenus. Additionally, the dorsal opening of the foramen vasculare distale in Antarctoboenus is larger than in any other known falconid (Fig. 3a 1). Similarly, the large plantar opening and the proximal location of this foramen in Antarctoboenus resembles the condition observed in Polyborinae (excepting Spiziapteryx), contrasting with the reduced and distally placed opening of the remaining falconids (only in Micrastur this foramen is as proximal as in Polyborinae, but it is very small). Plantarly, 
(a)

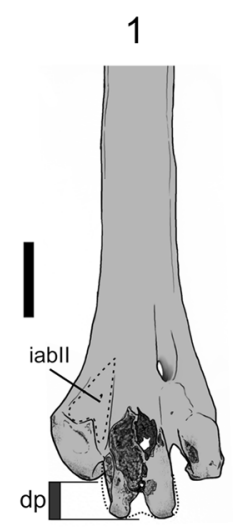

(b)
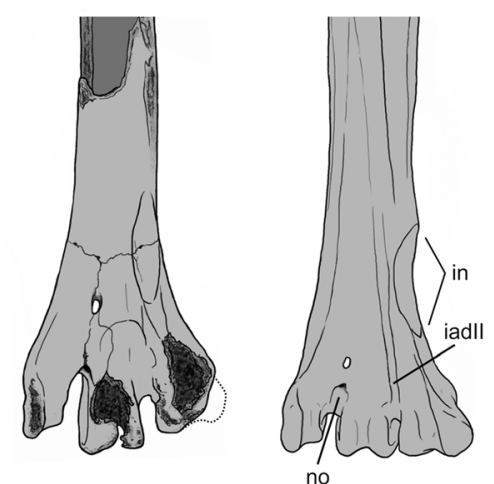

(c)

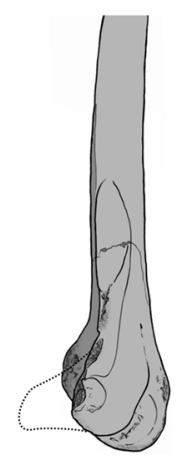

(d)

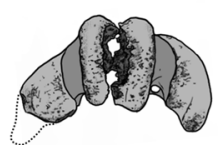

2
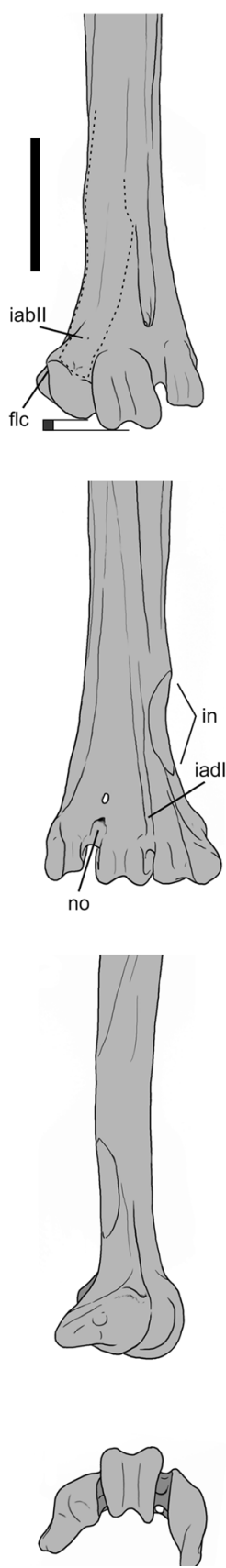

3
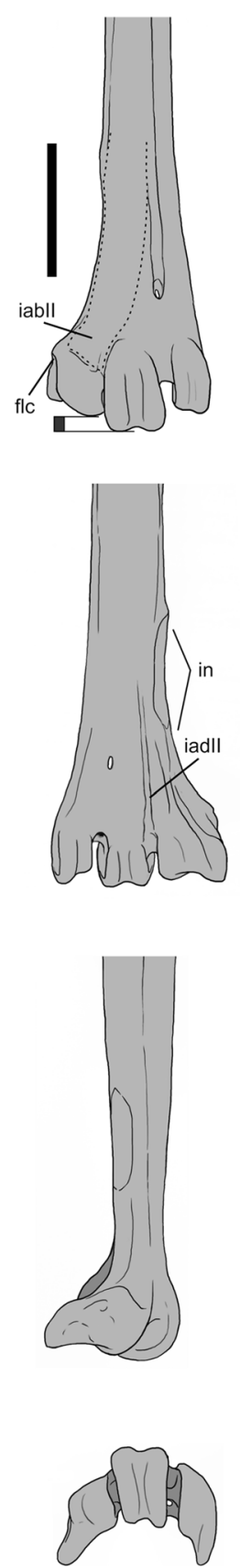

Fig. 3 Comparative tarsometatarsal morphology of Antarctoboenus carlinii nov. gen. nov. sp. and representatives of the major extant falconid lineages. a Distal end of left tarsometatarsus in dorsal view. b Idem, plantar view. c Idem, medial view. d Idem, and distal view. 1 Antarctoboenus carlinii, MLP 95-I-10-8, holotype. 2 Herpetotheres cachinnans, MACN 54484. 3 Micrastur semitorquatus, CFA-OR-498.

the tendinal impression of the adductor digiti II is indistinguishable in Antarctoboenus, differing from the weak, but well defined attachment of Polyborinae and Falconinae, and the large and deep mark of Herpetotherinae (Jollie 1976; Noriega et al. 2011; Fig. 3b, iadII). As in
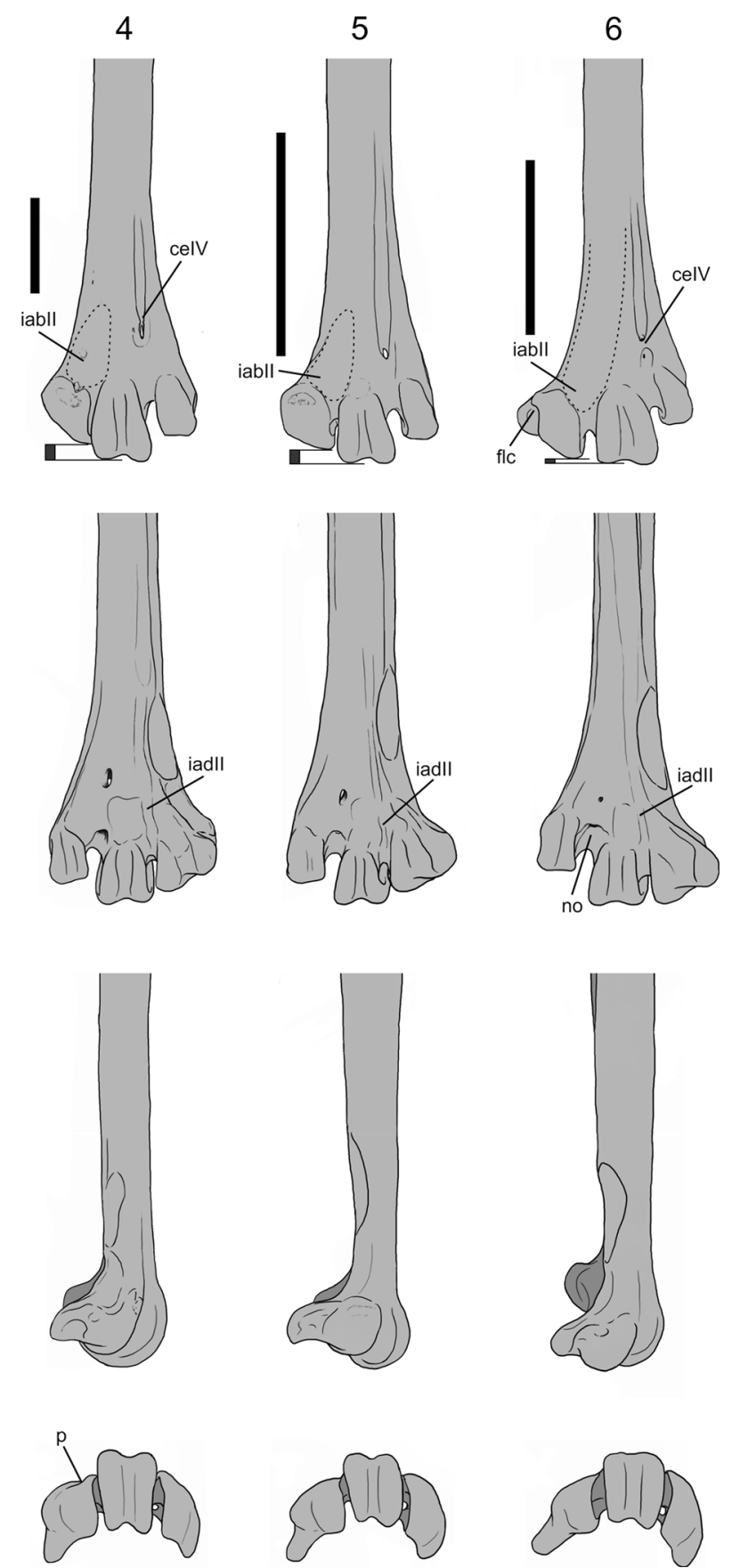

4 Polyborus plancus, CFA-OR-027-2. 5 Spiziapteryx circumcincta, MACN 23601. 6 Falco femoralis, MACN 54810. ceIV canalis for $\mathrm{m}$. extensor brevis digiti IV, $f l c$ constriction (fovea lig. collateralis), iabII insertion area of $\mathrm{m}$. abductor digiti II, iadII impresio $\mathrm{m}$. adductor digiti II, in indentation, no notch of the canalis interosseus distalis, $p$ pit. Scale bar $10 \mathrm{~mm}$

Polyborinae and Falconinae, the fossa metatarsi I in Antarctoboenus is larger and more distal than in Micrastur. In Herpetotheres and Thegornis the fossae exhibit similar widths and positions than that of Antarctoboenus, but are more excavated. This fossa in A. carlinii resembles that of 
Falconinae, Pediohierax and the small Polyborinae (e.g. Milvago, Spiziapteryx), whereas in Polyborus and Phalcoboenus it is better defined and larger. Concerning the development of the fossa metatarsi I, Antarctoboenus also shares with Polyborinae and Falconinae the absence of a large indentation on the medial surface of the bone, which is also typical of the Herpetotherinae (excepting Thegornis), being more pronounced and elongated in Micrastur than in Herpetotheres (Fig. 3b, in). In these latter taxa, this indentation exhibits a medial projection at its proximal part, which is clearly observable in dorsal and plantar views.

In dorsal view, the area for attachment of $\mathrm{m}$. abductor digiti II on trochlea metatarsi II in A. carlinii is reduced or proximodistally shortened (not continuous with the sulcus extensorius) and does not surpass laterally the midline of shaft, resembling the overall generalized morphology of Polyborinae. Contrarily, in Herpetotherinae this area is large and slightly concave (Fig. 3a, iabII), surpassing the midline of shaft laterally and extending largely towards the proximal end to join the wide and deep sulcus extensorius. This condition is similar, but less marked in Falco, where the muscular attachment and the sulcus extensorius are shallower than in Herpetotherinae. Additionally, the distal surface of this attachment area above trochlea metatarsi II is smooth in Falconinae and Herpetotherinae, whereas in Antarctoboenus and Polyborinae it presents rugosities and/ or conspicuous pits (in Polyborus and Phalcoboenus, with a well-marked pit above dorsal surface of trochlea in distal view; Fig. 3 d4, p; see also Jollie 1976, Fig. 142Ab).

On the plantar surface, Antarctoboenus shares with Micrastur, Thegornis, Polyborinae, and Pediohierax, a canalis interosseus distalis completely ossified along its whole extent, with its distal opening situated above the incisura intertrochlearis lateralis or a little bit more proximoplantarly. On the contrary, Herpetotheres and Falconinae have a canalis briefly (Jollie 1976) or not ossified (e.g. some Falco spp., Polihierax semitorquatus), exhibiting a proximally extended plantar notch (Fig. 3b, no) and its distal opening opens on plantar surface. Antarctoboenus presents a fossa supratrochlearis plantaris relatively deep as in Polyborinae and Falconinae and different to the condition found in Herpetotherinae.

The distal projection of trochlea metatarsi II is smaller than that of trochlea metatarsi III compared to any other known falconid. In dorsal view, trochleae metatarsorum II and IV extend distally to the same level, not surpassing half the length of trochlea metatarsi III. In the remaining falconids, the trochlea metatarsi II projects more distally than trochlea IV, largely beyond half the length of trochlea III. Besides, only some species of Falco have the trochlea metatarsi IV shorter than that of A. carlinii. In dorsal view, the slight medial divergence of trochlea II in A. carlinii seems to be unique within falconiforms. Although the medio-plantar rim of trochlea metatarsi II is lost in the holotype, the presence of a wing or process emerging from the articular body can be inferred from the preserved base observed in medial and plantar views. Beyond its smaller size, the overall shape of trochlea II is similar to that of Polyborinae because its articular body lacks the proximomedial constriction (Fig. 3a, flc) dorsally observed in Herpetotherinae, Pediohierax, and Falconinae. This constriction is always clearly notable when the fovea lig. collateralis can be seen dorsally. Thus, the medio-plantar process of the trochlea II in A. carlinii and the Polyborinae is plantarly directed and avoids the visibility of the fovea lig. collateralis, whereas the constriction seems to be well developed when the medio-plantar process of the trochlea is more medially projected.

Although Antarctoboenus has the trochlea metatarsi III partially eroded, its plantar articular surface seems to be elongated as in Polyborinae, Pediohierax, and Falconinae, differing from the very short and wide trochlea present in Herpetotherinae. As in Polyborinae, in dorsal view, this trochlea is not medially inclined as in Falconinae, Herpetotherinae, and Thegornis. In distal view, plantar rims of trochlea metatarsi III are rounded, not pointed as in other falconids, but this state could be due to weathering. In plantar view, the lateral rim of trochlea metatarsi IV projects more distally than the medial one in A. carlinii, as in Herpetotherinae, whereas both rims have similar projections in Polyborinae and Falconinae. In distal view, trochlea metatarsi IV is more laterally oriented in A. carlinii than in Herpetotherinae, as in Polyborinae and Falconinae (excepting Polihierax), and the plantar process of its lateral rim is shorter than in the latter.

In plantar view, Antarctoboenus carlinii differs from other falconids by having an incisura intertrochlearis lateralis deeper (extending more proximally than the proximal end of trochlea metatarsi III), whereas, in distal view, both incisurae are wider than those of other falcons.

\section{Discussion and conclusions}

Because of similarities in habits and morphology, members of the family Falconidae have been traditionally grouped within the order Falconiformes (e.g. sensu Wetmore 1960) together with raptors belonging to Accipitridae (hawks and allies) and other diurnal birds of prey (i.e. Cathartidae, Sagittariidae, and Pandionidae). However, anatomical studies (Jollie 1976, 1977a, b, c) have shown that similarities between falcons and hawks are not due to close phylogenetic relationship, but mainly to convergence. Recent molecular phylogenies agreed with this arrangement (e.g. Ericson et al. 2006; Hackett et al. 2008; 
McCormack et al. 2013; Yuri et al. 2013), giving support to a new clade (i.e. Australaves; see Ericson 2012; Jarvis et al. 2014), which includes falcons and allies together with seriemas (Cariamiformes), parrots (Psittaciformes), and passerine birds (Passeriformes). Our comparative analysis demonstrates that Antarctoboenus carlinii shares with Falconidae and differs from Accipitridae (auct. Accipitriformes) in the following characters (see also Jollie 1976; Noriega et al. 2011; Cenizo and Tassara 2013): (1) absence of irregular crest above the distolateral margin of fossa metatarsi I; (2) trochlea metatarsi II more proximally positioned than trochlea III; (3) medial process of trochlea metatarsi II slimmer, less conical, with blunt apex, more plantarly directed and clearly separated from trochlear body; (4) plantar articular surface of trochlea metatarsi II weakly grooved; (5) more slight depression (fovea lig. collateralis) above medial surface of trochlea metatarsi II; (6) trochlea metatarsi III more symmetrical; (7) trochlea metatarsi IV narrower and well directed laterally.

In the current phylogenetic context, Falconidae constitutes the unique extant family included within the order Falconiformes (see Remsen et al. 2008, SACC Proposal \#290, 2008). However, some analyses have recovered a sister relationship between the Falconidae and Cariamidae (Ericson et al. 2006; Ericson 2008; Wang et al. 2012), even has been proposed the inclusion of Cariamidae in Falconiformes (Ericson 2012). In this sense, Antarctoboenus carlinii shares with Falconidae and differs from Cariamidae in several characters including: (1) more elongated fossa metatarsi I and situated further distally; (2) absent sulcus for musculus extensor hallucis longus on the medial surface of the distal shaft; (3) trochlea metatarsi II with a large medial projection on the plantar surface and much wider than the trochlea metatarsi IV; (4) in distal view, trochleae metatarsorum arranged in arch; (5) dorsoplantarly shorter trochlea metatarsi III.

The palaeontological record of Falconidae is especially meager during Paleogene times and early assignments are most dubious (Mayr 2009). This is the case for Parvulivenator watteli from the Lower Eocene of England based on a distal end of tarsometatarsus and some associated phalanges (Harrison 1982) and of a second specimen referred to the same taxon (Mayr 2005) that was later discarded as a raptor and proposed to represent a coliform bird (Mayr 2005, 2009). Stintonornis mitcheli, also from Lower Eocene deposits of England and referred to a purported Falconidae, is represented by a third distal tarsometatarsus (Harrison 1984). Mourer-Chauviré (2006) also pointed out the presence of still undescribed falconids from the Upper Eocene and Lower Oligocene of the Phosphorites du Quercy in France. Finally, Masillaraptor parvunguis is a lower Middle Eocene taxon from Messel (Germany) known by two largely complete specimens
(Mayr 2006) and originally related to Polyborinae (Peters 1988, 1991). Unfortunately, the trochleae metatarsorum in both specimens of $M$. parvunguis are very poorly preserved precluding any comparison with $A$. carlinii. Further, the phylogenetic affinities of Masillaraptor are difficult to establish because it shares a combination of homoplastic characters with Accipitridae and Falconidae, i.e. two unrelated raptor lineages (see Mayr 2006, 2009). Thus, evidence of Paleogene falconid fossils outside South America are best regarded as unconfirmed.

Neogene fossils (Fig. 4) include the tiny extinct falcon Pediohierax ramenta from the Middle Miocene of Nebraska which was postulated as the sister taxon of Falconinae (Becker 1987). In South America, the earliest records of falcons come from Early Miocene of Patagonia and include three taxa. Badiostes patagonicus was originally described as an owl (Ameghino 1895), but later transferred to Falconidae (Wetmore 1922; Lambrecht 1933; Brodkorb 1964) and its affinities proposed to be with Polyborinae (Olson 1985). Thegornis musculosus and T. debilis are the other two valid species recently revised and included within the Herpetotherinae as the sister taxon of H. cachinnans (Noriega et al. 2011). Other scattered or fragmentary specimens referred to falconids have been mentioned for the Early to Late Miocene of Patagonia (Tonni 1980; Chiappe 1991), but unfortunately they have not yet been described. The first undoubted records of Polyborinae (i.e. Milvago sp.) were reported from the Late Miocene of Central Argentina (Cenizo et al. 2012) and Late Pliocene of Chile (Emslie and Guerra Correa 2003).

The holotypical specimen of Antarctoboenus carlinii was cited for the first time in a short communication, assigned to Falconidae and its affinities to Polyborinae pointed out (Tambussi et al. 1995). Although the Antarctic specimen had never been properly described nor compared, its relationship with Caracaras was uncritically accepted and sustained throughout two decades (e.g. Tambussi and Acosta Hospitaleche 2007; Tambussi and Degrange 2013; Reguero et al. 2013). Moreover, the material was never illustrated until recently (Tambussi and Acosta Hospitaleche 2007; Reguero et al. 2013). Tambussi and Acosta Hospitaleche (2007:607) stated that specimen MLP 95-I10-8 "exhibits a morphology similar to living polyborines in having the trochlea for the second digit shorter and wider than the trochlea for the digit four, bearing a plantarly projection" (see also Tambussi and Degrange 2013). However, these similarities between $A$. carlinii and the Polyborinae seem to be faintly supported from a phylogenetic point of view. The plantar projection of trochlea metatarsi II and its greater width than trochlea IV are generalized characters not only within Polyborinae, but in all falconids. On the other hand, the Polyborines, as well as all falconids (including the extinct Thegornis and 


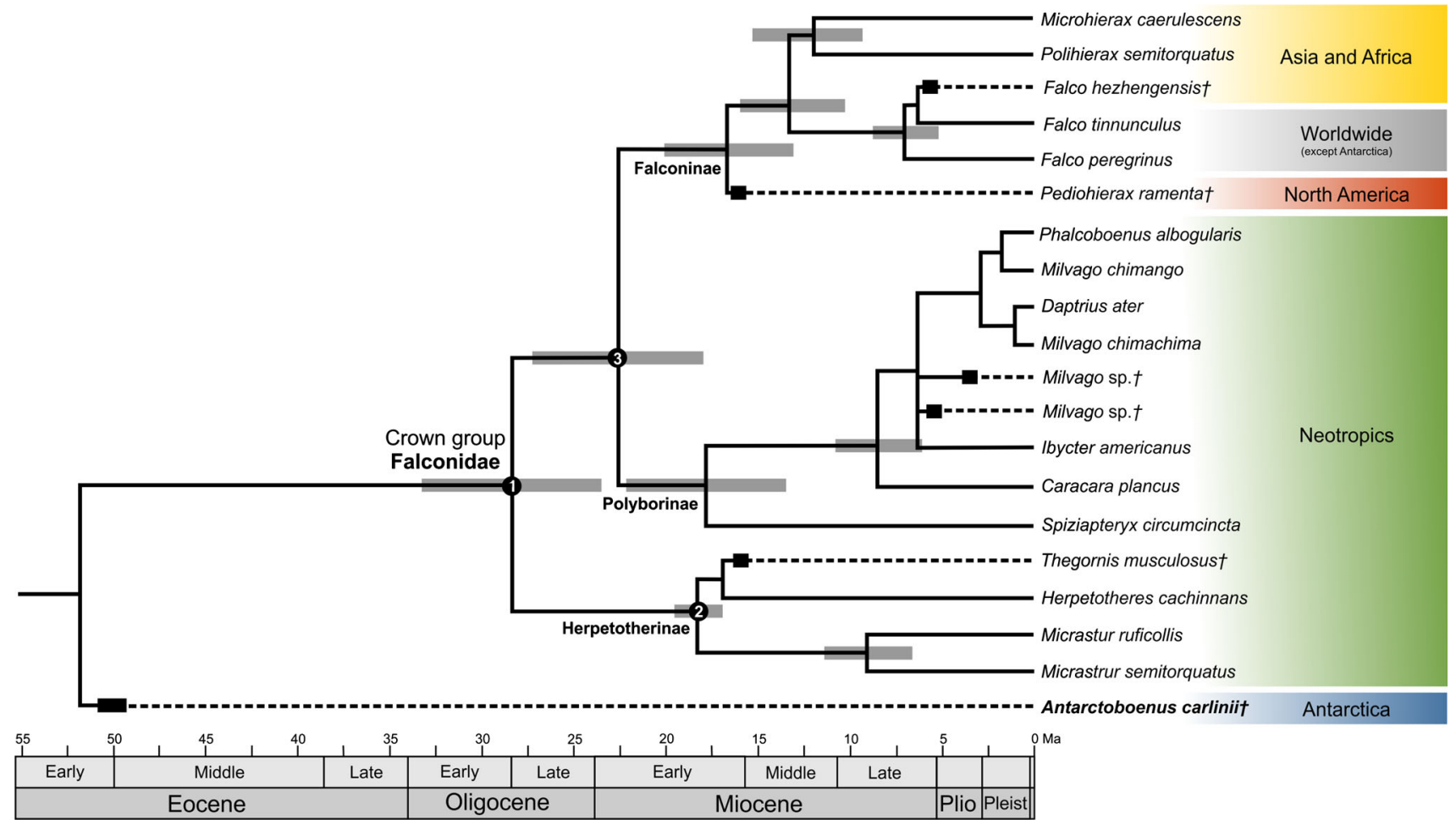

Fig. 4 Geographical range, temporal distribution, and phylogenetic affinities of extant and fossil falconid birds. The internal nodes are supported by the following presumably derived features: (1) welldefined sulcus extensorius, impression of $\mathrm{m}$. adductor digiti II present, trochlea metatarsi II distally projected beyond half the trochlea III, strong medial divergence of trochlea metatarsi II; (2) cross-section of midshaft not squared, developed crista dorsalis medialis, prominent cristae plantaris medialis et lateralis, wide and deep impression of $\mathrm{m}$. adductor digiti II, shallow fossa supratrochlearis plantaris; (3) sulcus extensorius generally closed distally by a bony canal on the dorsal opening of foramen vasculare distale, medial and lateral ridges of

Pediohierax) present a trochlea metatarsi II longer (i.e. more distally extended) than trochlea metatarsi IV. Contrarily, both trochleae have similar distal spreadings because the trochlea metatarsi II is remarkably shorter in $A$. carlinii. Indeed, Mayr (2009) was the first to notice this striking morphological difference.

From the above-cited features and our remaining detailed descriptions, it can be inferred that $A$. carlinii has very close affinities to the crown group Falconidae; however, several derived characters of the latter are absent in $A$. carlinii (e.g. sulcus extensorius well developed, trochlea metatarsi II more distally extended than trochlea IV, dorsal opening of the foramen vasculare distal reduced, impression of tendon del $\mathrm{m}$. adductor digiti II well-marked; Fig. 4).

With the exception of the diagnostic characters described above, the morphology of A. carlinii is more similar to that of Caracaras than to any other falconid. In accordance with our hypothesis, previous authors had pointed out that trochlea metatarsi IV distally projected at the same level. Backbone phylogeny of extant taxa after Fuchs et al. (2015), inferred from mitochondrial and nuclear sequence data. Affinities of extinct taxa Thegornis, Pediohierax, and Falco hezhengensis were taken from osteological phylogenies performed by Noriega et al. (2011); Becker (1987); and $\mathrm{Li}$ et al. (2014), respectively, and we follow the taxonomic criteria of Cenizo et al. (2012) and Emslie and Guerra Correa (2003) for the fossil specimens of Milvago sp. The temporal distribution of fossil taxa (dagger) is indicated by black squares. Grey bars indicate divergence times estimates for the primary lineages within the extant Falconids according to Fuchs et al. (2015)

tarsometatarsal morphology in Polyborinae is possibly very close to the primitive condition found in the family (Jollie 1976, 1977c; Olson 1976; Becker 1987). We think that the original relationships postulated between A. carlinii and Polyborinae are based on plesiomorphic characters retained in the tarsometatarsus of the latter clade.

Fuchs et al. (2015) stated that the Antarctic specimen described herein could potentially constitute a stem Falconidae if their divergence time analyses were correct (i.e. this fossil would be too ancient to belong to the crown group if the oldest estimate for the first Falconidae split was at 34.8 million years ago; Fig. 4).

In sum, we consider that $A$. carlinii represents the most primitive falconiform taxon until now known and belongs to the early evolutive radiation of this raptorial lineage. Our interpretation, although being exclusively based on anatomical characters, contradicts prior inferences about the systematic assignment and concomitant phylogenetic affinity of the Antarctic specimen (Tambussi et al. 1995; 
Tambussi and Acosta Hospitaleche 2007; Tambussi and Degrange 2013), reinforcing the hypothesis about the Neotropical or Austral origin of Falconidae as suggested by molecular phylogenies (Ericson et al. 2006; Ericson 2012; Fuchs et al. 2015).

Acknowledgments We thank Y. Davies (MACN), P. Tubaro (MACN), H. Alvarenga (MHNT), and S. Bogan (FHN) for assistance during our visits to collections under their care. We especially acknowledge the Instituto Antártico Argentino and Fuerza Aérea Argentina, which provided logistical support for our participation in the Antarctic fieldwork. Finally, we thank B. Lindow and an anonymous reviewer for their helpful comments on the manuscript.

\section{References}

Ameghino F (1895) Sur les Oiseaux fossiles de Patagonie. Bol Inst Geogr Arg 15:301-660

Baumel J, Witmer LM (1993) Osteologia. In: Baumel J, King A, Breazile $J$ et al (eds) Handbook of avian anatomy: nomina anatomica avium. Publ Nuttall Orn $\mathrm{Cl}$, Massachusetts, pp $45-132$

Becker JJ (1987) Revision of "Falco" ramenta Wetmore and the Neogene evolution of the Falconidae. Auk 104:270-276

Brodkorb P (1964) Catalogue of fossil birds. Part II. Anseriformes through Galliformes. Bull Florida State Mus 8:195-335

Cenizo M, Tassara D (2013) Nuevos registros fósi-les del Halcón Plomizo (Falco femoralis Temminck, 1822; Falconidae) en el Pleistoceno del centro-este de Argentina. Historia Natural 3:13-30

Cenizo M, Tambussi CP, Montalvo CI (2012) Upper Miocene continental birds from the Cerro Azul Formation in Pampean Region (South-Central Argentina). Alcheringa 36:47-68

Chiappe LM (1991) Fossil birds from the Miocene Pinturas Formation of Southern Argentina. J Vert Paleontol 11:21A-22A

Emslie SD, Guerra Correa C (2003) A new species of penguin (Spheniscidae: Spheniscus) and other birds from the late Pliocene of Chile. Proc Biol Soc Wash 116:308-316

Ericson PGP (2008) Current perspectives on the evolution of birds. Contrib Zool 77:109-116

Ericson PGP (2012) Evolution of terrestrial birds in three continents: biogeography and parallel radiations. J Biogeogr 39:813-824

Ericson PGP, Anderson CL, Britton T et al (2006) Diversification of Neoaves: integration of molecular sequence data and fossils. Bio Lett 2:543-547

Feduccia A (1996) The origin and evolution of birds. Yale University, New Haven and London

Ferguson-Lees J, Christie DA (2001) Raptors of the World. Houghton Mifflin Company, Boston

Fuchs J, Chen S, Johnson JA, Mindell DP (2011) Pliocene diversification within the South American forest-falcons (Falconidae: Micrastur). Mol Phylogenet Evol 60:398-407

Fuchs J, Johnson JA, Mindell DP (2012) Molecular systematics of the caracaras and allies (Falconidae: Polyborinae) inferred from mitochondrial and nuclear sequence data. Ibis 154:520-532

Fuchs J, Johnson JA, Mindell DP (2015) Rapid diversification of falcons (Aves: Falconidae) due to expansion of open habitats in the Late Miocene. Mol Phylogenet Evol 82:166-182

Griffiths CS (1999) Phylogeny of the Falconidae inferred from molecular and morphological data. Auk 116:116-130

Griffiths CS, Barrowclough GF, Groth JG, Mertz L (2004) Phylogeny of the Falconidae (Aves): a comparison of the efficacy of morphological, mitochondrial, and nuclear data. Mol Phylogenet Evol 32:101-109

Hackett SJ, Kimball RT, Reddy S et al (2008) A phylogenomic study of birds reveals their evolutionary history. Science 320:1763-1767

Harrison CJO (1982) A new tiny raptor from the Lower Eocene of England. Ardea 70:77-80

Harrison CJO (1984) Further additions to the fossil birds of Sheppey: a new falconid and three small rails. Tert Res 5:179-187

Jarvis ED, Mirarab S, Aberer AJ et al (2014) Whole-genome analyses resolve early branches in the tree of life of modern birds. Science 346:1320-1331

Jollie M (1976) A contribution to the morphology and phylogeny of the Falconiformes. Pt. I. Evol Theor 1:285-298

Jollie M (1977a) A contribution to the morphology and phylogeny of the Falconiformes. Pt. II. Evol Theor 2:115-208

Jollie M (1977b) A contribution to the morphology and phylogeny of the Falconiformes. Pt. III. Evol Theor 2:209-300

Jollie M (1977c) A contribution to the morphology and phylogeny of the Falconiformes. Pt. IV. Evol Theor 3:1-142

Lambrecht K (1933) Handbuch der Palaeornithologie. Verlag Gebrüder Borntraeger, Berlin

Li Z, Zhou Z, Deng T, Li Q, Clarke JA (2014) A falconid from the Late Miocene of northwestern China yields further evidence of transition in Late Neogene steppe communities. Auk 131:335-350

Marenssi SA, Santillana SN, Rinaldi CA (1998) Stratigraphy of La Meseta Formation (Eocene), Marambio Island, Antarctica. In: Casadío S (ed) Paleógeno de América del Sur y de la Península Antártica. Revista de la Asociación Paleontológica Argentina, Publicación Especial 5, pp 137-146

Mayr G (2005) The Paleogene fossil record of birds in Europe. Biol Rev 80:515-542

Mayr G (2006) A new raptorial bird from the Middle Eocene of Messel, Germany. Historical Biol 18:95-102

Mayr G (2009) Paleogene fossil birds. Springer, Heidelberg

McCormack JE, Harvey MG, Faircloth BC et al (2013) A phylogeny of birds based on over 1500 loci collected by target enrichment and high-through put sequencing. PLoS One 8:e54848

Montes M, Nozal F, Santillana S, Marenssi S, Olivero E (2013) Mapa Geológico de Isla Marambio (Seymour), Antártida; escala 1:20.000. $1^{\mathrm{a}}$ edición. Serie Cartográfica

Mourer-Chauviré C (2006) The avifauna of the Eocene and Oligocene Phosphorites du Quercy (France): an updated list. Strata 13:5-149

Noriega JI, Areta JI, Vizcaíno SF, Bargo MS (2011) Phylogeny and Taxonomy of the Patagonian Miocene Falcon Thegornis musculosus Ameghino, 1895 (Aves: Falconidae). J Paleo 85:1089-1104

Olson SL (1976) The affinities of the falconid genus Spiziapteryx. Auk 93:633-636

Olson SL (1985) The fossil record of birds. In: Farner DS, King JR, Parkes KC (eds) Avian biology, vol 8. Academic Press, New York, pp 79-238

Peters DS (1988) Fossil birds from the oil shale of Messel (Lower Middle Eocene). In: Ouellet H (ed) Acta XIX Congressus Internationalis Ornithologici. University of Ottawa, Ottawa, pp 2056-2064

Peters DS (1991) Zoogeographical relationships of the Eocene avifauna from Messel (Germany). In: Bell B, Cossee RO, Flux JEC et al (eds) Acta XX Congressus Internationalis Ornithologici. New Zealand Ornithological Congress Trust Board, Christchurch, pp 572-577

Reguero MA, Goin F, Acosta Hospitaleche C, Dutra T, Marenssi SA (2013) Late Cretaceous/Eocene West Antarctica Biota and Its 
Intercontinental Affinities. Springer Briefs in Earth System Sciences

Remsen JV, Cadena CD, Jaramillo A et al (2008) A classification of the bird species of South America. Proposal no. 383. http://www. museum.lsu.edu/ Remsen/SACCBaseline.html. American Ornithologists' Union

Tambussi CP, Acosta Hospitaleche C (2007) Antarctic birds (Neornithes) during the Cretaceous-Eocene times. Rev Asoc Geol Arg 62:604-617

Tambussi CP, Degrange F (2013) South American and Antarctic Continental Cenozoic Birds: Paleobiogeographic Affinities and Disparities. Springer Briefs in Earth System Sciences

Tambussi CP, Noriega JI, Santillana S, Marenssi S (1995) Falconid bird from the Middle Eocene La Meseta Formation, Seymour Island. West Antarctica. J Vert Paleontol 15:55A

Tonni EP (1980) The present state of knowledge of the Cenozoic birds of Argentina. Contr Sci Mus Nat His Los Angeles 330:104-114

Wang N, Braun EL, Kimball RT (2012) Testing hypotheses about the sister group of the Passeriformes using an independent 30 locus dataset. Mol Biol Evol 29:737-750
Wetmore A (1922) Remains of birds from caves in the Republic of Haiti. Smithson Misc Collect 74:1-4

Wetmore A (1936) Two new species of hawks from the Miocene of Nebraska. Proc USA Nat Mus 84:73-78

Wetmore A (1960) A classification for the birds of the world. Smithson Misc Collect 139:1-37

White CM, Olsen PF, Kiff LF (1994) Family Falconidae (Falcons and Caracaras). In: del Hoyo J, Elliot A, Sargatal J (eds) Handbook of the Birds of the World, vol 2., New World Vultures to GuineafowlLynx Edicions, Barcelona, pp 216-275

Wink M, Sauer-Gürth H (2004) Phylogenetic relationships in diurnal raptors based on nucleotide sequences of mitochondrial and nuclear marker genes. In: Chancellor RD, Meyburg BU (eds) Raptors Worldwide. World Working Group on Birds of Prey, Berlin; and MME/BirdLife Hungary, Budapest, pp. 483-498

Yuri T, Kimball RT, Harshman J et al (2013) Parsimony and modelbased analyses of indels in avian nuclear genes reveal congruent and incongruent phylogenetic signals. Biology 2:419-444 